\title{
Factors Influencing Elderly People With Cognitive Impairment
}

\author{
$* 1^{\text {st }}$ Rosli Hanjani \\ Nursing Bachelor Study Program \\ Universitas Harapan Bangsa \\ Purwokerto, Indonesia \\ roeslimuhamad@gmail.com
}

\author{
$2^{\text {nd }}$ Noor Rochmah Ida AyuTrisno Putri \\ Nursing Bachelor Study Program \\ Universitas Harapan Bangsa \\ Purwokerto, Indonesia \\ noorrochmah@uhb.ac.id
}

\author{
$3^{\text {rd }}$ Dwi Novitasari \\ Nursing Bachelor Study Program \\ Universitas Harapan Bangsa \\ Purwokerto, Indonesia \\ dwinovitasari@uhb.ac.id
}

\begin{abstract}
Elderly people with Cognitive impairment have various possible impacts on their psychological, social life, and physical activities. The purpose of this study was to determine factors influencing the elderly people with cognitive impairment. This descriptive study used a cross-sectional approach conducted at the Village Integrated Service Unit of Community Health Center Gandrungmangu II (known as UPTD Puskesmas Gandrungmangu II) by involving108 respondents. Two questionnaires consisting of questionnaire $A$ and B were distributed. Questionnaire A was related to the respondent's demographic characteristics, such as age, gender, education level, diabetes mellitus (DM) history, and hypertension history. Meanwhile, questionnaire $B$ which was related to the Mini Mental State Examination (MMSE) assessed the respondents' cognitive functions. Univariate and Chi Square analysis were employed to analyze the data. There was a significant relationship between age $(p$-value $=0.003)$, gender $(p$-value $=0.002)$, education level $(p$-value $=0.00)$, diabetes mellitus (DM) history $(p$-value $=0.002)$, and hypertension history $(\mathrm{p}$-value $=\mathbf{0 . 0 5})$. Nursing care was given to the elderly people with cognitive impairment by considering various factors. A comprehensive assessment was then conducted to reveal those known influencing the elderly people with the decreasing cognitive functions
\end{abstract}

\section{Keywords-Cognitive Impairment, elderly people}

\section{INTRODUCTION}

Elderly is one specific growth stage and development process. Elderly is defined as people with certain physical characteristics, such as gray hair, wrinkled skin, and teeth loss [1]. Law number 13 Year 1998 defines on elderly as someone aged 60 years old or more [2]. Elderly people will experience various changes related to their physiological, psychological, and social aspects. These changes occur at a certain chronological age development and are considered as a normal process [3].

Aging is a natural process that will bee experienced by all people through 3 life stages: childhood, adulthood, and old age[4]. Aging is a process in which the body tissues gradually lost their ability to repair, replace, and maintain their normal functions. A person will slowly experience this process and realize that the body can no longer repair the occurring damages and be resistant to any possible infection. Furthermore, the decreasing physical, mental, and social functions experienced by the elderly people make them feel unhappy [1].
Aging is a decreasing process of body immune system to the external stimuli which gradually results in someone's cumulative change and not considered as a disease [2]. Old age is a period in which the body is no longer resistant tothe occurring damages since the body has lost its ability to repair the damaged tissues[3]. Aging may cause several changes to the brain compositions due to the degenerating neurons and oligodendrocytes resulting in cognitive impairment experienced by the elderly people [5]. The Cognitive impairment includes recalling difficulty, weakening ability to make decisions, and slowing responses[6].

The cognitive impairment is more commonly experienced by the elderly people aged between $75-90$ years old $(50 \%)$ than those aged between $60-74$ years $(27.7 \%)$. The cognitive impairment is also more experienced by the elderly people with the education level of only elementary school $(62.5 \%)$ than those with higher education level [6]. People's awareness and knowledge on elderly people with cognitive impairment are still relatively poor. They consider that the cognitive impairment is a part of natural aging processes. If not properly treated, these prolonged cognitive impairment functions may influence the elderly people's daily activities [7].

Without proper treatments, these decreasing cognitive functions may lead to more serious problems. It was reported by the surrounding people living in the working area of the Village Integrated Service Unit of Community Health Center Gandrungmangu II(known as UPTD Puskesmas Gandungmangu II) that without the family members' supervision, the elderly people more frequently made mistakes in taking the prescribed medication. Some studies related the decreasing cognitive functions experienced bythe elderly peoplehave been frequently conducted yet ignored the history of certain diseases and other related factors. History of certain diseases may fasten the decreasing cognitive functions experienced by the elderly people.

The results of a preliminary study conducted by some researchers in November 2019 onthe cognitive functions of people aged 60 years old or older living around the working area of the Village Integrated Service Unit of Community Health Center Gandrungmangu II(known as UPTD Puskesmas Gandungmangu II)by distributing the MMSE questionnaires showed that $44.45 \%$ respondents had normal cognitive functions, $22.22 \%$ respondents experienced the probable cognitive impairment, and $33.33 \%$ respondents had 
the definite cognitive impairment. Due to the above mentioned preliminary results, the authors are interested in conducting further research to obtain a more complete understanding on the factors influencing the elderly people with the decreasing cognitive functions elderly people living around the working area of the Village Integrated Service Unit of Community Health Center Gandrungmangu II (known as UPTD Puskesmas Gandungmangu II).

\section{METHOD}

This descriptive correlation research was conducted using a cross sectional approach. The research subjects were 108 elderly people living around the working area of the Village Integrated Service Unit of Community Health Center Gandrungmangu II(known as UPTD Puskesmas Gandungmangu II)selected using a probability sampling method with several inclusion criteria, such as able to communicate in both Indonesian and Javanese language, able to read and write, and having diabetes mellitus (DM) or hypertension history. The samples size was calculated using the Slov in formula with the correlation value of $10 \%$ to avoid the missing data.

The Ethical clearance was obtained after completing a research proposal reviewed by the Ethics Committee of Universitas Harapan Bangsa. The researchers have distributed the written informed consents to the respondents before collecting the data. 2 questionnaires were used as the measuring instruments. Questionnaire A contains respondent's identity including age, sex, education level, and diabetes mellitus (DM) or hypertension history. Questionnaire B is related to the Mini Mental State Examination (MMSE) questionnaire consisting of several items related to the cognitive functions, such as orientation, retention, attention, recall, and language. The data was then analyzed using both univariate and bivariate (chisquare)Analysis.

\section{RESULT AND DISCUSSION}

The univariate analysis on the respondents' characteristics showed that most $(72.2 \%)$ respondents were in the same age range or over 65 years old with the average age of 67.35 years old and Standard Deviation of 5.397 as shown in table 1.

TABLE I. RESPONDENTS'CHARACTERISTICS

\begin{tabular}{|c|c|c|c|c|}
\hline Age & Frequency & Percentage & Mean & Std. Deviation \\
\hline $60-64$ & 30 & 27.8 & 67.35 & 5.397 \\
\hline$>65$ & 78 & 72.2 & & \\
\hline Total & 108 & 100.0 & & \\
\hline
\end{tabular}

The distributions of respondents' characteristics also showed that most respondents were female $(65.7 \%)$, has with low education level (87\%), no diabetes mellitus (DM)history $(89.8 \%)$, and no hypertension history $(54.6 \%)$ as shown in table 2 .
TABLE II. RESPONDENTS' CHARACTERISTICS

\begin{tabular}{|c|c|c|c|}
\hline & Variable & Number & Percentage (\%) \\
\hline Sex & Male & 37 & 34.3 \\
\cline { 2 - 4 } & Female & 71 & 65.7 \\
\hline $\begin{array}{c}\text { Education } \\
\text { Level }\end{array}$ & Low & 94 & 87.0 \\
\hline Hiabetesmell & Yes & 14 & 13.0 \\
\hline $\begin{array}{c}\text { Diab(DM)hist } \\
\text { itus }\end{array}$ & No & 97 & 10.2 \\
\hline $\begin{array}{c}\text { ory } \\
\text { Hypertensio } \\
\text { n history }\end{array}$ & Yes & 49 & 89.8 \\
\hline & No & 59 & 45.4 \\
\hline
\end{tabular}

The Chi-Square testing results on the elderly people with cognitive impairment related to their age showed that 2 respondents aged 60-64 years old experienced definitive cognitive impairment, 17 respondents experienced probable cognitive impairment, and 11 respondents had normal cognitive functions. The statistical testing results showed that the significance value ( $\mathrm{p}$-value) was $0.003(<0.05)$, meaning that there was a significant relationship between age and cognitive impairment experienced by the elderly people.

TABLE III. RELATIONSHIP BETWEEN AGE AND COGNITIVE IMPAIRMENT

\begin{tabular}{|c|c|c|c|c|c|c|}
\hline \multirow[t]{2}{*}{ Sex } & \multicolumn{3}{|c|}{ MMSE } & \multicolumn{2}{|c|}{ Total } & \multirow{2}{*}{$\begin{array}{c}\mathrm{P} \\
\text { Value }\end{array}$} \\
\hline & Definitive & Probable & Normal & $\mathrm{N}$ & $\%$ & \\
\hline $60-64$ & 2 & 17 & 11 & 30 & 27.8 & \multirow[t]{3}{*}{0.003} \\
\hline$\geq 65$ & 30 & 23 & 25 & 78 & 72.2 & \\
\hline Total & 32 & 40 & 36 & 108 & 100 & \\
\hline
\end{tabular}

71 female respondents $(65.7 \%)$ showed various cognitive statuses. 16 female respondents had normal cognitive functions, 27 female respondents had definitive cognitive impairment, and 28 female respondents had probable cognitive impairment. The p-value was 0.00 , meaning that there was a relationship between gender and cognitive impairment experienced by the elderly people as shown in table 4.

TABLE IV. RELATIONSHIP BETWEENGENDER AND COGNITIVE IMPAIRMENT

\begin{tabular}{|c|c|c|c|c|c|c|}
\hline \multirow[t]{2}{*}{ Sex } & \multicolumn{3}{|c|}{ MMSE } & \multicolumn{2}{|c|}{ Total } & \multirow{2}{*}{$\begin{array}{c}\mathrm{P} \\
\text { Value }\end{array}$} \\
\hline & Definitive & Probable & Normal & $\mathrm{N}$ & $\%$ & \\
\hline Male & 5 & 12 & 20 & 37 & 34.3 & \multirow[t]{3}{*}{0.002} \\
\hline Female & 27 & 28 & 16 & 71 & 65.7 & \\
\hline Total & 32 & 40 & 36 & 108 & 100 & \\
\hline
\end{tabular}

TABLE V. RELATIONSHIP BETWEEN EDUCATION LEVELAND COGNITIVE IMPAIRMENT

\begin{tabular}{|c|c|c|c|c|c|c|}
\hline \multirow{2}{*}{$\begin{array}{l}\text { Education } \\
\text { level }\end{array}$} & \multicolumn{3}{|c|}{ MMSE } & \multicolumn{2}{|c|}{ Total } & \multirow{2}{*}{$\begin{array}{c}\mathrm{P} \\
\text { Value }\end{array}$} \\
\hline & Definitive & Probable & Normal & $\mathrm{N}$ & $\%$ & \\
\hline Low & 32 & 40 & 22 & 94 & 87 & \multirow[t]{3}{*}{0.00} \\
\hline Higher & 0 & 0 & 14 & 14 & 13 & \\
\hline Total & 32 & 40 & 36 & 108 & 100 & \\
\hline
\end{tabular}

Table 5 shows that 94 respondents $(87 \%)$ had lower education level, 22 respondents had normal cognitive functions, 40 respondents had probable cognitive impairment, and 32 respondents had definitive cognitive 
impairment. The Chi-Square testing results showed that the p-value was 0.00 , meaning that there wasa significant relationship between education level and cognitive impairment experienced by the elderly people.

Furthermore, most respondents $(89.8 \%)$ did not have diabetes mellitus(DM)history, and 37 respondents had probable cognitive impairment, 36 respondents had normal cognitive functions, and 24 respondents experienced definitive cognitive impairment. The statistical test shown inTable 6 showed that the p-value was 0.002 , meaning that there was a relationship between diabetes mellitus(DM)history and cognitive impairment experienced by the elderly people.

TABLE VI. RELATIONSHIP BETWEEN DIABETES MELLITUS (DM) HISTORY AND COGNITIVE IMPAIRMENT

\begin{tabular}{|l|c|c|c|c|c|c|}
\hline Diabetes & \multicolumn{3}{|c|}{ MMSE } & \multicolumn{2}{c|}{ Total } & $\begin{array}{c}\mathrm{P} \\
\text { Valu } \\
\text { Mellitus(D }\end{array}$ \\
M)History & Definitive & Probable & Normal & N & $\%$ & e \\
\hline Yes & 8 & 3 & 0 & 11 & 10.2 & 0.002 \\
\hdashline No & 24 & 37 & 36 & 97 & 89.8 & \\
\hline Total & 32 & 40 & 36 & 108 & 100 & \\
\hline
\end{tabular}

TABLE VII. RELATIONSHIP BETWEENHYPERTENSION HISTORY AND COGNITIVE IMPAIRMENT

\begin{tabular}{|c|c|c|c|c|c|c|}
\hline \multirow{2}{*}{$\begin{array}{l}\text { History of } \\
\text { Hypertensi } \\
\text { on }\end{array}$} & \multicolumn{3}{|c|}{ MMSE } & \multicolumn{2}{|c|}{ Total } & \multirow{2}{*}{$\begin{array}{c}\mathrm{P} \\
\text { Value }\end{array}$} \\
\hline & Definitive & Probable & Normal & $\mathrm{N}$ & $\%$ & \\
\hline Yes & 20 & 14 & 15 & 49 & 45.4 & \multirow[t]{3}{*}{0.05} \\
\hline No & 12 & 26 & 21 & 59 & 54.6 & \\
\hline Total & 32 & 40 & 36 & 108 & 100 & \\
\hline
\end{tabular}

Table 7 shows that $45.4 \%$ respondents had hypertension history, 20 respondents experienced definitive cognitive impairment, 14 participants experienced probable cognitive impairment, and 15 respondents had normal cognitive function. The Chi-Square testing results showed in a significance $\mathrm{p}$-value of 0.05 , meaning that there was a significant relationship between hypertension history and cognitive impairment experienced by the elderly people.

Most (83\%) respondents were aged between 60-64 years old and the others were at the same age or over 65 years old. This category was in accordance with the age groups issued by the Ministry of Health (2006) in Rosidah (2017). It is also mentioned that the elderly people whose age were 60 years old or over were described in Law Number 13 Year 1998 Chapter I Article 1 paragraph 2 [2]. As the age increases, the elderly people will experience a faster cognitive function decrease in the right part of the brain than the left one resulting in cognitive impairment [8].

The decreasing cognitive function before 50 years old is considered abnormal and pathologic. The cognitive function changes are commonly experienced by those reaching their 70's. Once reaching the age of 65-75 years old, some abilities will gradually decrease, and at the age of 80 years old, more abilities will significantly decrease [9]. In this research, there were $27.8 \%$ younger elderly people and $72.2 \%$ older elderly people ( $>65$ years old). The Chi-Square testing results related to the relationship between age and cognitive impairment experienced by the elderly people living around the working area of the Village Integrated Service Unit of Community Health Center Gandrungmangu
II(known as UPTD Puskesmas Gandungmangu II) showed a significance of 0.003 , meaning that age had a significant relationship with cognitive impairment experienced by the elderly people.

This research finding is in line with that conducted by Deharnita et al.,2016 [9] explaining that the statistical testing results showed that the p-value was equal to 0.024 (Pvalue $<0.05$ ), meaning that there was a significant relationship between age and cognitive impairment experienced by the elderly people Found at the Sabai Nan AluihSicincin elderly people nursing home in 2016. This is also in accordance with the literature saying that the increasing age may result in physiological changes, such as the shrinking brain size and biochemical changes in Central Nervous System which eventually lead to the cognitive impairment.

Along with the increasing age, people will face a greater risk to experience cognitive impairment, especially women. Sex is a character used as one basic principle to identify the differences between men and women based on their behavioral, mentality, and emotional aspects. Women entering the old age have a higher risk of experiencing senility by 1,393 times or three times greater than men as women have a longer life expectancy [10]. Higher life expectancy causes women have a greater cognitive impairment. The Chi-Square testing results showed a significance of 0.002 , meaning that sex has a relationship with cognitive impairment experienced by the elderly people living around the working area of the Village Integrated Service Unit of Community Health Center Gandrungmangu II (known as UPTD Puskesmas Gandungmangu II).

This research finding is also supported by that conducted by Coresa and Ngestiningsih [11] stating that there was a relationship between sex and cognitive impairment experienced by the elderly people. Older women have a greater risk of experiencing cognitive impairment due to the result of endogenous sex hormones which contribute to the cognitive function changes [10]. Based on the results of this research result, severe cognitive impairmentwas greatly experienced by the female elderly people than the male ones.

A research conducted by Permanaet al., on 1,000 elderly people in Changsa City, China, showed that the MMSE scores in men are higher than those in women [12]. The results of this study were in accordance with a theory stating that female elderly people had a greater risk of experiencing cognitive impairment than the male ones. Female elderly people will find their estrogen hormone a vital component for brain function performance, decreases that eventually influence the elderly peoples' cognitive functions [13].

This research showed that the respondents' education level was still relatively low, proven by the data showing that most respondents did not finish their primary education, yet some graduated from elementary school or junior high school. The respondents' low education level was due to the lack of formal education facilities at that time and economic factors that that most respondents had low education level. They prefer working o going to school since education was extremely expensive. 
Education is one aspect considerably influencing the development of one's cognitive functions. Elderly people with nine years education background or more commonly have normal cognitive functions [14]. Education is a process of adding life experiences and intellectual stimulations which may influence someone's cognitive functions. Low education level means less mental and environmental experiences as well as less intellectual stimulations resulted from the respondents' lack of mental and environmental experiences. The results of this research showed that $87 \%$ respondents only had a primary education level, meaning that the education level of those elderly people living around the working area of the Village Integrated Service Unit of Community Health Center Gandrungmangu II(known as UPTD Puskesmas Gandungmangu II)was still relatively low. Low education level may result in lack of personal ability to think and become creative. Furthermore, lack of knowledge is also associated with the minimal use of brain ability to discover new things and eventually lead to the cognitive impairment.

This research finding showed the Chi-Square results on the relationship between education level and cognitive impairment experienced by the elderly people was 0.000 , meaning that there was a relationship between education level and cognitive impairment experienced by the elderly people. Education is a process of adding life experiences and intellectual stimulations which will influence someone's cognitive functions. A low education level is associated with less mental and environmental experiences which possibly impact on short intellectual stimulations and result in poor cognitive performance. Low education levelis one risk factor to the cognitive impairment [15].

This research found that 11 of 108 respondents living around the working area of the Village Integrated Service Unit of Community Health Center Gandrungmangu II(known as UPTD Puskesmas Gandungmangu II)had diabetes mellitus (DM) history. Diabetes Mellitus (DM) is a serious chronic disease due to the failure of pancreas in producing enough insulin (a hormone regulating the blood sugar or glucose) or when the body cannot effectively use the produced insulin. The number of diabetes mellitus (DM) case and its prevalence of continuously increase over the last few decades [16]. The diabetes mellitus (DM) prevalence based on the doctors' diagnoses on the population aged of $\geqslant 15$ years oldreferring to the data obtained from the National Basic Health Research (known as Riskesdas) in 2018 increased by $2 \%$ when compared to that in 2013 [17]. Diabetes mellitus (DM) also has an important role in the cognitive impairment experienced by the elderly people. Diabetes mellitus (DM)history also had a significant relationship with cognitive impairment experienced by the elderly people living around the working area of the Village Integrated Service Unit of Community Health Center Gandrungmangu II (known as UPTD Puskesmas Gandungmangu II), as shown in Table 6. Moreover, the pvalue resulted from the influence of independent variable of DM history to the dependent variable of cognitive impairment experienced by the elderly peoplewas 0.002 . This research finding was in accordance with that conducted by Mongisidi R et al., 2013 [14] stating that respondents with diabetes mellitus (DM) history significantly influenced cognitive impairment
45.4\% respondents had hypertension history. Hypertension is one factor which has an important role in cognitive impairment experienced by the elderly people. Hypertension experienced by the elderly people may influence the structural damage of substantia alba (the white matter of central nervous system) due to the presence of blood flow peripheral resistance to the substantia alba region which causes the vasoconstriction remain in the blood vessels that the blood flow decreases and leads to arteriosclerosis which results in periventricular lesions inhibiting the impulse delivery transmissions from the central nervous system to the peripheral. This complicated process may influence the peripheral sensory and motoric fibers connecting the cortical area with thalamus, basal ganglia, cerebellum, and medulla spinalis or spinal cord that this process also influences the elderly people's cognitive functions.

Based on the data obtained in this research, it showed that hypertension had a significant relationship with cognitive impairment experienced by the elderly people. The Chi-Square test between hypertension history and cognitive impairment experienced by the elderly people living around the working area of the Village Integrated Service Unit of Community Health Center Gandrungmangu II (known as UPTD Puskesmas Gandungmangu II) with the $p$-value of 0.05 , meaning that there was a significant relationship between cognitive impairment experienced by the elderly peopleand hypertension history. This finding is in accordance with that conducted by Rahmayanti [18] stating that there was a significant relationship between hypertension and cognitive impairment experienced by the elderly people.

\section{CONCLUSION}

This research involveda total of 108 respondents to figure out the factors influencing the cognitive impairment experienced by the elderly peopleliving around the working area of the Village Integrated Service Unit of Community Health Center Gandrungmangu II(known as UPTD PuskesmasGandungmangu II).It is concluded that there is a significant relationship of age, sex, education level, diabetes mellitus (DM) history and hypertension historywith cognitive impairment experiencedby the elderly people.

\section{REFERENCES}

[1] Azizah. 2011. KeperawatanLanjutUsia [Elderly People Nursing Care]. Yogyakarta: Grahallmu

[2] Republik Indonesia. 1998. Undang-UndangRepublik Indonesia No 13 tentangKesejahteraanLanjutUsia [Law No. 13 on the Welfare of Elderly People]. Indonesia

[3] Miller, C. A. 2012. Nursing for Wellness in Older Adults (6th ed.). China: Wolters Kluwer Health, Lippincott Williams \& Wilkins.

[4] Mubarak, W.I., Chayatin, N., \&Santoso, B.A. 2010. Ilmu Keperawatan Komunitas Konsep dan Aplikasi [Nursing Science: Community, Concept, and Application], Jakarta: SalembaMedik

[5] Saputri. 2015. Perbedaan Fungsi Kognitif sebelum dan sesudah pelatihan senam Lansia Menpora pada kelompok Lansia Kemuning [Different Cognitive Functions before and after the Menpora Elderly Gymnastic Training Given to Kemuning Elderly Group], Banyumanik, Semarang, KTI. Universitas Diponegoro

[6] Dayames, R. 2013. Gambaran fungsi kognitif klien usialanjut di posbindu rosella legoso wilayah kerja puskesmas ciputat timur tangeran selatan [The Description of Cognitive Functions of Elderly Clients at the Integrated Development Post (Posbindu) of rosella 
legoso around the working area of East Ciputat Community Health Center, South Tangerang].

[7] Manurung et al. 2016. Gambaranfungsikognitifpadalansia di DesaKokaKecamatanTombulu [The Description of Elderly People's Cognitive Functions in Koka Village, Tombulu District]. 4, 2-5.

[8] Aini, DN, danPuspitasari, 2016.

HubunganfungsiKognitifdengankualitashiduplansiadi

KelurahanBarusariKecamatan Semarang Selatan [The Relationship of Cognitive Function and Life Quality of Elderly People in Barusari Sub-district, South Semarang District]. Volume 7, Number 1, January 2016

[9] Kaunang, VindyDortje., Buanasar, Andi.,Kallo, Vandri. 2019. Gambaran Tingkat Stress PadaLansia [The Description of Elderly people's Stress Levels]. E-Journal (e-Kp) Volume 7 Number 2

[10] Maryatiet al. 2013. Gambaranfungsikognitifpadalansia di UPT PantiwerdhaMojopahitkabupatenMojokerto [The Description of Elderly People's Cognitive Functions at the Technical Implementation Unit of werdhaMojopahit Elderly House, Mojokerto Regency]. 1-6.

[11] Coresa, T., \&Ngestiningsih, D. 2017.Gambaran Fungsi Kognitif Pada Lansia Di Unit Rehabilitasi Sosial Pucang Gading Semarang. JurnalKedokteranDiponegoro [The Description of Elderly People's Cognitive Functions at the PucangGadingSocial Rehabilitation Unit, Semarang],6(1), 114-119.

[12] Permanaet al. 2019. Faktor-faktor yang berhubungan dengan penurunan kognitif pada lansia [Factors Related to the Cognitive People's Cognitive Impairment]https://dosenpsikologi.com/perubahan-kognitif-padalansia, accessed on 2 December 2019

[13] Wreksoatmodjo. (2014). Beberapa kondisi fisik dan penyakit yang merupakan faktor risiko gangguan fungsi kognitif [Some Physical Conditions and Diseases as the Risk Factors to Cognitive
Impairment]. CerminDuniaKedokteran [Medical WorldReflection]. 2014;41(1):25-32.

[14] Mongisidiet al., (2013). Profil penurunan fungsi kognitif pada lansia di yayasan-yayasanmanula di kecamatanKawangkoan [The Description of Elderly People's Cognition Impairment at Ederly Foundations in Kawangkoan District]. E-CliniC. https://doi.org/10.35790/ecl.1.1.2013.3297

[15] Rasyidet al. (2017). Hubungan faktor resiko dengan fungsi kognitif pada lanjut usia kecamatan Padang PanjangTimurkota Padang Panjang [The Relationship of Risk Factor with the Elderly People's Cognitive Functions in East Padang Panjang District, Padang City].http://jurnal.fk.unand.ac.id/index.php/jka/article/view/643/508,a ccessed on 2 December 2019.

[16] World Health Organization (WHO). 2016. Global Report On Diabetes.https://www.google.com/url?sa=t\&rct=j\&q=\&esrc=s\&sourc e=web\&cd=\&ved=2ahUKEwioxdCMv-

LpAhVs8XMBHeBNAusQFjAAegQIAhAB\&url=https $\% 3 \mathrm{~A} \% 2 \mathrm{~F} \% 2$ Fapps.who.int $\% 2$ Firis $\% 2$ Frest $\% 2$ Fbitstreams $\% 2 F 909883 \% 2 F r e t r i e v e$ \&usg=AOvVaw02AXavZxubgvureA1iwkxG. Accessed on 2 November 2019.

[17] Riskesdas [National Basic Health Research]. 2018. Hasil Utama Riskesdas [National Basic Health Research's Main Results]. Kementrian Kesehatan Badan Penelitian dan Pengembangan Kesehatan [Ministry of Health: Health Research and Development Body]

[18] Rahmayati, Y. 2018. Hubungan lama menderita Hipertensi dengan penurunan kognitif pada lansia [The Relationship between Length of Experiencing Hypertension and Elderly People's Cognitive impairment].

http://jurnal.abulyatama.ac.id/index.php/acehmedika/article/view/122/ 122, accessed on 2 December 2019 